Tsaqofiya : Jurnal Pendidikan Bahasa dan Sastra Arab

Vol. 4 No. 1 Januari 2022, 1-15

P-ISSN : 2685-7022, E-ISSN : 2685-7103

DOI: $10.21154 /$ tsaqofiya.v4i1.56

\title{
Desain Materi Ajar Berbasis Adobe Flash CS6 Untuk Meningkatkan Minat Belajar Bahasa Arab Mahasiswa IAIN Ponorogo
}

\author{
M. Nasrullah'1, Achmad Baihaqi ${ }^{2}$ \\ IAIN Ponorogo \\ 1ㅁasrullah752001@gmail.com, ${ }^{2}$ Abayhaque.qie@gmail.com
}

\section{Abstract}

The teaching process is now more focused on interactive media-based learning technology such as CDs, laptops and the Internet, but nowadays many teachers still maintain and use media only based on textbooks, so learning Arabic tends to be boring and student interest is very low. GMI.B students are the average graduates from public schools (SMK and SMA). The purpose of this study was to increase student interest in learning Arabic by designing teaching materials based on Adobe FlashCS6. This study uses the type of research R\&D (Research Development) with the ADDIE model, data is collected using observation, interviews, documentation, questionnaires and check lists techniques and then analyzed qualitatively and quantitatively descriptively with (T.test) test. $t$. Design of teaching materials for Arabic learning based on Adobe FlashCS6 for GMI.B students. The material expert validation stage and media expert validation both gave a score of "very good" and the product design of the textbook was declared "feasible" to be used as an Arabic language learning media application. The results of the pre-test test of interest in learning Arabic for GMI.B IAIN Ponorogo students before using the design of Arabic learning teaching materials based on Adobe FlashCS6 resulted in an average of 75.88. While the results of the post-test test of interest in learning Arabic for GMI.B IAIN Ponorogo students after using the design of Arabic learning teaching materials based on Adobe FlashCS6 resulted in an average of 87.88. Based on these results, it can be concluded that the use of Adobe FlashCS6-based Arabic learning teaching materials can effectively increase interest in learning Arabic for GMI.B IAIN Ponorogo students.

Keywords: Teaching materials, Adobe FlashCS6, interest in learning

\section{Asbtrak}

Proses pengajaran sekarang lebih menitik beratkan pada teknologi pembelajaran berbasis media interaktif seperti CD, laptop dan Internet, tetapi dewasa ini banyak juga pengajar yang masih mempertahankan dan menggunakan media hanya bersumber pada buku teks, sehingga pembelajaran bahasa Arab cenderung membosankan dan minat mahasiswapun sangat rendah. Mahasiswa GMI.B adalah rata-rata lulusan dari sekolah umum (SMK dan SMA). Tujuan penelitian ini adalah untuk meningkatkan minat mahasiswa dalam belajar bahasa Arab dengan desain materi ajar berbasis Adobe FlashCS6. Penelitian ini menggunakan jenis penelitian $R \& D$ (Research Development) dengan model ADDIE, data dikumpukan dengan 
tehnik observasi, wawancara, dokumentasi, angket dan check list kemudian dianalisis secara kualitatif dan kuantitatif-deskriptif dengan (T.test) Uji. t. Desain materi ajar pembelajaran bahasa Arab berbasis Adobe FlashCS6 bagi mahasiswa GMI.B. Tahap validasi ahli materi dan validasi ahli media keduanya memberikan skor "sangat baik" dan desain produk buku ajar dinyatakan "layak" untuk dipergunakan sebagai aplikasi media pembelajaran bahasa Arab. Hasil pengujian pre test minat belajar bahasa Arab mahasiswa GMI.B IAIN Ponorogo sebelum penggunaan desain materi ajar pembelajaran bahasa Arab berbasis Adobe FlashCS6 menghasilkan rata-rata sebesar 75,88. Sedangkan hasil pengujian post test minat belajar bahasa Arab mahasiswa GMI.B IAIN Ponorogo sesudah penggunaan desain materi ajar pembelajaran bahasa Arab berbasis Adobe FlashCS6 menghasilkan rata-rata sebesar 87,88. Berdasarkan hasil tersebut dapat disimpulkan bahwa penggunaan desain materi ajar pembelajaran bahasa Arab berbasis Adobe FlashCS6 efektif dapat meningkatkan minat belajar bahasa Arab mahasiswa GMI.B IAIN Ponorogo

Kata Kunci: Materi ajar, Adobe FlashCS6, minat belajar

\section{PENDAHULUAN}

Tujuan pembuatan bahan ajar, setidaknya ada empat hal pokok yang melingkupinya, yaitu: a) Membantu siswa dalam mempelajari sesuatu, b) Menyediakan berbagai jenis pilihan bahan ajar, sehingga mencegah timbulnya rasa bosan pada peserta didik, c) Memudahkan peserta didik dalam melaksanakan pembelajaran; dan d) Agar kegiatan pembelajaran menjadi lebih menarik. Adapun manfaat pembuatan bahan/materi ajar dapat dibedakan menjadi dua macam, yaitu kegunaan bagi pendidik dan kegunaan bagi peserta didik. ${ }^{1}$

Sementara kegunaan bagi peserta didik, Apabila bahan/materi ajar tersedia secara bervariasi, inovatif, dan menarik, maka paling tidak ada tiga kegunaan bahan/materi ajar bagi peserta didik, diantaranya sebagai berikut: a) Kegiatan pembelajaran menjadi lebih menarik, b) Peserta didik lebih banyak mendapatkan kesempatan untuk belajar secara mandiri dengan bimbingan pendidik; dan, c) Peserta didik mendapatkan kemudahan dalam mempelajari setiap kompetensi yang harus dikuasainya ${ }^{2}$. Sebagaimana amanat dari Ditjen Dikti Kemristekdikti RI menegaskan bahwa hakikat buku ajar perguruan tingggi adalah naskah yang ditulis oleh dosen dalam rangka menunjang materi pokok perkuliahannya, ditulis melalui paradigma kritis yang emansipatoris, terutama karena dalam rangka menegakkan

1 Jamaluddin Shiddiq, "Inovasi Pemanfaatan Word-Wall Sebagai Media Game-Based Learning Untuk Bahasa Arab," JALIE; Journal of Applied Linguistics and Islamic Education 5, no. 1 (2021): 151-69.

2 Andi Prastowo, Panduan Kreatif Membuat Bahan Ajar Inovatif (Yogyakarta: Diva Press, 2011). 
kebenaran ilmiah, buku ajar disajikan dalam rangka membuka cakrawala pengeatahuan mahasiswa ${ }^{3}$.

Salah satu unsur untuk membuka cakrawala mahasiswa dalam pembelajaran adalah penyajian materi berbasis multimedia berupa adob flash. Adobe Flash Professional CS6 merupakan software yang mampu menghasilkan presentasi, game, film, CD interaktif, maupun CD pembelajaran, serta untuk membuat situs web yang interaktif, menarik, dan dinamis. Adobe Flash Professional CS6 mampu melengkapi situs web dengan beberapa macam animasi, suara, animasi interaktif, dan lain-lain sehingga pengguna sambil mendengarkan penjelasan mereka dapat melihat gambar animasi, maupun membaca penjelasan dalam bentuk teks. Adobe Flash Professional CS6 sebagai software untuk pembuatan media pembelajaran interaktif berdasarkan pada beberapa kelebihan yang dimilikinya ${ }^{4}$. Adobe Flash Professional CS6 merupakan software yang dirancang untuk membuat animasi berbasis vector dengan hasil yang mempunyai ukuran kecil. Awalnya software ini diarahkan untuk membuat animasi atau aplikasi berbasis internet (online), namun dalam perkembangannya banyak digunakan untuk membuat animasi atau aplikasi yang bukan berbasis internet (offline). Dengan Action Script 3.0 yang dibawanya, Adobe Flash Professional CS6 dapat digunakan untuk mengembangkan game atau bahan ajar seperti kuis atau simulasi ${ }^{5}$.

Minat adalah interest berarti kecenderungan dan kegairahan tinggi atau keinginan yang besar terhadap sesuatu. Minat seperti yang dipahami dan dipakai oleh orang selama ini dapat mempengaruhi hasil kualitas belajar siswa dalam bidang-bidang studi tertentu. Kemudian karena pemusatan yang intensif terhadap bidang atau materi itulah yang memungkinkan siswa untuk lebih giat dan akhirnya mencapai prestasi yang diinginkan ${ }^{6}$.

Seseorang yang berminat dalam aktivitas maka dimanapun akan memperhatikan secara konsisten dan senang tanpa adanya beban. Minat pada dasarnya adalah penerimaan akan suatu hubungan antara diri sendiri dengan

3 Wahyu Wibowo, Penulisan Buku Ajar Perguruan Tinggi: Hakekat, Formulasi Dan Problem Etisnya (Jakarta: Penerbit RajaGrafindo Persada, 2012), 13.

4 Ariesto Hadi Sutopo, Teknologi Informasi Dan Komunikasi Dalam Pendidikan (Yogyakarta: Graha Ilmu, 2012), 60.

5 Ikas Shofiani, "Modul Pelatihan Pembuatan Media Pembelajaran Menggunakan Adobe Flash CS3 Professional. Diakses Dari Https://Ikashofiani.Files.Wordpress.Com/2012/05/Modul-PelatihanAdobe- Flash-Cs3-Professional.Pdf Pada Tanggal 28 November 2015," 2012, 9.

6 Muhibbin Syah, Psikologi Pendidikan Dengan Pendeketan Baru (Bandung: Rosdakarya, 2006), 136. 
sesuatu yang ada di luar. Semakin kuat atau dekat hubungan tersebut, semakin besar minat tersebut ${ }^{7}$.

\section{PEMBAHASAN}

\section{Studi Pendahuluan}

Pada tahap ini dilakukan analisis terhadap problematika yang yang dihadapi mahasiswa ketika mempelajari bahasa Arab dan bagaimana sistematika penyusunan bahan ajar dengan multimedia menyenangkan serta desain materi yang efektif dan efisien.

Multimedia yang dikembangkan berdasarkan analisis kebutuhan dari berbagai informasi tentang minat mahasiswa dalam mempelajari bahasa Arab. Pengumpulan informasi dilakukan dengan tehnik wawancara dan observasi. Data yang diperoleh dalam studi pendahuluan.

(a) Observasi

Observasi dilakukan untuk mengetahui proses pembelajaran berlangsung, perihal yang diamati bagaimana kesulitan mahasiswa dalam mempelajari bahasa Arab serta kondisi kelas. Dalam pembelajaran peneliti sering menggunakan strategi Cooperative Learning berbasis Jigsaw, artinya setiap orang dalam kelompok punya tugas sendiri-sendiri dan tugas tersebut harus dipresentasikan di hadapan teman satu kelas. Ketika mengerjakan tugas per kelompok hanya lulusan dari pesantren yang lebih aktif, adapun mahasiswa lulusan dari non pesantren cenderung aktif bertanya karena mereka belum bisa memberikan kontribusi pada kelompoknya berupa.

(b) Wawancara

Untuk mendapatkan informasi tentang proses dalam pembelajaran bahasa Arab di kelas peneliti mewawancarai dengan beberapa mahasiswa, adapun jawaban dari mahasiswa GMI.B mengenai proses pembelajaran sebagai berikut.

"Saya belum pernah belajar bahasa arab menggunakan multimedia, dan saya merasa senang, ada sesuatu yang baru bagi saya"

Berdasarkan hasil wawancara menunjukkan bahwa mahasiswa menginginkan ada inovasi baru dalam mengajarkan bahasa Arab agar suasana

\footnotetext{
${ }^{7}$ Syaiful Bahri Jamarah, Psikologi Belajar Edisi 2 (Jakarta: PT.Rineka Cipta, 2008), 166.
} 
pembelajaran juga lebih fokus dengan tampilan media yang menarik dan mereka mereka bisa mengerjakan tugas/PR (Pekerjaan Rumah) dilakukan secara mandiri.

(c) Penyusunan Instrument

Instrument yang digunakan dalam pengambilan data di lapangan disusun berdasarkan kisi-kisi instrument. Instrument yang digunakan berupa lembar angket untuk mahasiswa, ahli materi, dan ahli media. Angket yang ditujukan ahli materi dan ahli media berisi indikator-indikator yang dijadikan pedomana dalam memberikan penilaian terhadap multimedia sebelum diujicobakan kepada subyek uji coba yaitu mahasiswa. Masukan berupa komentar, kritik dan saran dari ahli dijadikan pedoman dalam revisi dan perbaikan produk untuk mendapatkan kata keterbacaan sebelum diuji cobakan.

(d) Angket

Angket untuk mahasiswa berisi pertanyaan-pertanyaan yang berkaitan dengan multimedia pembelajaran yang dikembangkan. Mahasiswa diminta memberikan nilai dengan cara memilih salah satu dari 5 skala yang disediakan ${ }^{8}$.

Berdasarkan data angket menunjukkan bahwa penyampaian materi pembelajaran bahasa Arab dengan aplikasi odobe flash CS6 bagi mahasiswa GMI.B kebanyakan mereka menjawab dengan kualifikasi "sangat setuju" mengacu pada pedoman konversi data kuantitatif ke dalam kualitatif, maka produk aplikasi Adobe Flash CS6 yang dikembangkan termasuk dalam kategori “ baik” dengan nilai 8,25. Adapun yang kurang setuju hanya 1,02. Hal itu bermakna aplikasi odobe flash CS6 tersebut telah berhasil merubah paradigm mahasiswa yang awalnya tidak suka terhadap mata kuliah bahasa Arab menjadi lebih senang dan antusias..

\section{Pengembangan Produk}

Pengembangan produk dimulai dengan mendesain multimedia pembelajaran bahasa Arab. Desain multimedia ini mengacu pada informasi dari mahasiswa lulusan non pesantren (SMK dan SMA), analisis kurikulum, Silabus, dan kebutuhan dosen pengampu mata kuliah bahasa Arab 1.

8 Dkk. I Made Tegeh, Model-Model Penelitian Pengembangan (Yogyakarta: Graha Ilmu, 2014), 103. 
Pembuatan desain awal multimedia bahasa Arab dimulai dengan menetukan konsep dan tema yang akan digunakan. Konsep dan tema yang dipilih merupakan gambaran yang akan mewakili ide dari pengembangan yang disesuaikan dengan hasil pengumpulan informasi pada tahap sebelumnya, yang diharapkan dapat sesuai dengan kebutuhan mahasiswa non pesantren sehingga nantinya, multimedia tersebut menjadi media yang memiliki keterbacaan yang baik serta menarik dan menyenangkan dan bisa dipelajari secara mandiri.

\section{Pengembangan Bentuk Produk Awal}

Produk awal yaitu menyeleksi materi dan menyusun secara sistimatis berdasarkan teori pembelajaran bahasa Arab bagi pemula Pada tahap ini juga dilakukan pembuatan media dalam bentuk prototype menggunakan software Adobe Flash Professional CS6 sesuai dengan perancangan yang telah dibuat. Seluruh isi materi pembelajaran dimasukkan termasuk didalamnya membuat animasi pada beberapa pokok bahasan.

\section{Penilaian Produk oleh Ahli}

Produk yang telah diselesaikan telah selesai dikembangkan berupa desain multimedia. Produk terlebih dahulu dilakukan pengecekan dan penilaian oleh para ahli sebelum produk tersebut diajarkan atau di ujicobakan kepada mahasiswa GMI.B Penilaian (validasi produk) dilakukan melalui expert judgmenet. Supaya mengetahui kelebihan dan kelemahan dari produk yang telah dikembangkan maka dilakukan penilaian (validasi) oleh ahli yang kompeten sesuai bidangnya. Validasi dilakukan oleh ahli materi dan ahli media. Data validasi oleh ahli materi dan ahli media sebagai berikut:

\section{a) Validasi Ahli Materi}

Validasi yang dilakukan oleh ahli materi mencakup aspek isi (content) materi yang disajikan dalam media pembelajaran berupa Adobe Flash CS6. Ahli materi dalam pengembangan multimedia bahasa Arab bagi mahasiswa GMI.B adalah Ibu Alibaul Chusna, M.Si. Dosen bahasa Arab IAIN Ponorogo sekaligus sebagai pengampu/dosen mata kuliah Desain Materi Ajar Bahasa Arab. Ahli materi mengevaluasi materi yang tertulis dalam aplikasi Adobe Flash CS6 serta memberikan masukan berupa komentar dan saran demi perbaikan materi yang ada. Validasi dengan ahli materi dilakukan 27 Agustus 2019 di Fakultas 
Tarbiyah dan Ilmu Keguruan IAIN Ponorogo. Adapun validasi ahli materi dapat dilihat pada tabel dibawah ini:

Tabel 1. Hasil validasi

\begin{tabular}{|c|c|c|c|}
\hline No & Indikator & Nilai & Kriteria \\
\hline 1 & $\begin{array}{l}\text { Ketepatan judul bab dengan isi materi dalam } \\
\text { tiap bab }\end{array}$ & 5 & $\begin{array}{l}\text { Sangat } \\
\text { baik }\end{array}$ \\
\hline 2 & Kejelasan petunjuk pada tiap bab & 5 & $\begin{array}{l}\text { Sangat } \\
\text { baik }\end{array}$ \\
\hline 3 & Kejelasan kerangka isi & 4 & Baik \\
\hline 4 & $\begin{array}{l}\text { Kesesuaian antara standart kompetensi dengan } \\
\text { indikator hasil belajar }\end{array}$ & 5 & $\begin{array}{l}\text { Sangat } \\
\text { baik }\end{array}$ \\
\hline 5 & $\begin{array}{l}\text { Kesesuaian antara indikator hasil belajar dan } \\
\text { paparan materi }\end{array}$ & 5 & $\begin{array}{l}\text { Sangat } \\
\text { baik }\end{array}$ \\
\hline 6 & Kejelasan uraian materi & 5 & $\begin{array}{l}\text { Sangat } \\
\text { baik }\end{array}$ \\
\hline 7 & Kejelasan contoh-contoh yang diberikan & 5 & $\begin{array}{l}\text { Sangat } \\
\text { baik }\end{array}$ \\
\hline 8 & Kesesuaian antara gambar/ilustrasi dan materi & 5 & $\begin{array}{l}\text { Sangat } \\
\text { baik }\end{array}$ \\
\hline 9 & Kejelasan tugas dan latihan yang diberikan & 5 & $\begin{array}{l}\text { Sangat } \\
\text { baik }\end{array}$ \\
\hline 10 & $\begin{array}{l}\text { Kesesuaian antara tugas dan latihan dengan } \\
\text { materi }\end{array}$ & 5 & $\begin{array}{l}\text { Sangat } \\
\text { baik }\end{array}$ \\
\hline 11 & Ketepatan pemilihan isi rangkuman & 4 & Baik \\
\hline 12 & $\begin{array}{l}\text { Kesesuaian antara tes akhir bab dengan } \\
\text { indikator hasil belajar }\end{array}$ & 5 & $\begin{array}{l}\text { Sangat } \\
\text { baik }\end{array}$ \\
\hline 13 & $\begin{array}{l}\text { Ketepatan sumber pendukung yang didapat } \\
\text { dijadikan acuan mencari sumber bacaan yang } \\
\text { relevan dengan materi }\end{array}$ & 5 & $\begin{array}{l}\text { Sangat } \\
\text { baik }\end{array}$ \\
\hline 14 & $\begin{array}{l}\text { Memberi kesempatan kepada mahasiswa untuk } \\
\text { belajar mandiri maupun kelompok }\end{array}$ & 5 & $\begin{array}{l}\text { Sangat } \\
\text { baik }\end{array}$ \\
\hline & Jumlah & 68 & \\
\hline
\end{tabular}

Penilaian ahli pada tahap ini berjumlah total 68 dari 14 pertanyaan dengan nilai rata-rata 5. Berdasarkan pedoman konversi data kuantitatif ke dalam kualitatif, maka produk materi yang ada dalam multimedia Adobe Flash CS6 yang dikembangkan termasuk dalam kategori "sangat baik". Artinya produk tersebut bisa diujicobakan kepada mahasiswa GMI.B

b) Validasi Ahli Media

Validasi yang dilakukan oleh ahli media dilihat dari segi keterbacaan aplikasi yang dikembangkan dalam pembelajaran. Ahli media dalam 
pengembangan aplikasi ini adalah Bapak Dr. Harjali, M.Pd dosen Teknologi Pendidikan IAIN Ponorogo.

Validasi tahap ini dilakukan pada 28 Agustus 2019. Bertempat di kantor Fakultas Tarbiyah dan Ilmu Keguruan (FATIK) IAIN Ponorogo. Data yang diperoleh bisa dilihat pada tabel berikut:

\section{Tabel 2. Hasil Validasi}

\begin{tabular}{llcl} 
No & \multicolumn{1}{c}{ Unsur yang dinilai } & Nilai & \multicolumn{1}{c}{ Kriteria } \\
\hline 1 & Kualitas cover & 5 & Sangat baik \\
\hline 2 & Kemenarikan desain cover & 5 & Sangat baik \\
\hline 3 & Ketepatan lay out & 4 & Baik \\
\hline 4 & $\begin{array}{l}\text { Kesesuaian antara ilustrasi/gambar dengan } \\
\text { materi }\end{array}$ & 5 & Sangat baik \\
\hline 5 & Kejelasan tulisan/pengetikan & 5 & Sangat baik \\
\hline 6 & $\begin{array}{l}\text { Kelengkapan komponen-komponen pada } \\
\text { setiap bab buku ajar }\end{array}$ & 4 & Baik \\
\hline 7 & Kesesuaian ukuran huruf dan gambar & 5 & Sangat baik \\
\hline 8 & Kemudahan dalam penggunaan & 5 & Sangat baik \\
\hline 9 & $\begin{array}{l}\text { Mendukung tingkat pemahaman } \\
\text { mahasiswa terhadap materi dan } \\
\text { keterampilan dalam pembelajaran }\end{array}$ & 4 & Sangat baik \\
\hline 10 & $\begin{array}{l}\text { Tingakt kreativitas pada desain Adobe } \\
\text { Flash CS6 } \quad \text { Jumlah }\end{array}$ & 5 & Sangat baik \\
\hline & $\quad$ Rata-rata & 48 &
\end{tabular}

Jumlah indikator yang dinilai dari ahi media pembelajaran sebanyak 10 soal, hasilnya penilaian pada tahap ini memperoleh nilai 47 dengan nilai ratarata 4,7 berdasarkan pedoman konversi data kuantitatif ke data kualitatif, maka produk buku ajar yang dikembangkan termasuk kategori "sangat baik" artinya produk aplikasi Adobe Flash CS6 bisa ujiucobakan dengan mahasiswa.

\section{Uji Coba Produk}

Tahap uji coba dilakukan tiga level yaitu uji coba kategori perorangan, uji coba kategori sedang dan uji coba lapangan. Peneliti tidak melakukan ujicoba level kategori perorangan, ujicoba kategori sedang, dan ujicoba lapangan.

a) Uji Coba Perorangan (Individual)

Uji coba pada level ini atau preliminary field testing dilakukan untuk memperoleh data. Data observasi, wawancara, angket dikumpulkan kemudian dianalisis. Pada level ini peneliti melakukan uji coba dengan 3 orang mahasiswa kelas GMI.B IAIN Ponorogo. Yang dipilih sebelum mereka masuk 
IAIN mereka adalah lulusan dari SMA dan SMK dengan kemampuan bahasa Arabnya rendah. Uji coba tahap ini dilakukan pada tanggal 04 September 2019.

Responden diminta untuk melihat ilustrasi/gambar dan membaca isi materi yang ada dalam aplikasi Adobe Flash, kemudian mahasiswa diberi lembar evaluasi (angket) untuk menilai keterbacaan dari produk tersebut.

Data kuantitatif yang diperoleh melalui angket dengan rating scale dianalisi dengan statistik deskriptif kemudia dikonversi ke data kualitatif dengan skala 5 untuk mengetahui kualitas produk. Konversi yang dialkukan terhadap data kualitatif mengacu pada rumus konversi yang dikemukakan oleh Eko P Widiyoko ${ }^{9}$. Adapun hasil uji coba perorangan bisa dilihat pada tabel berikut ini:

Tabel 3. hasil uji coba perorangan

\begin{tabular}{clcccccl}
\multirow{2}{*}{ No } & Indikator & \multicolumn{3}{c}{ Mahasiswa } & Jumlah & Rata- & Kriteria \\
\cline { 2 - 5 } & & $\mathbf{1}$ & $\mathbf{2}$ & $\mathbf{3}$ & skor & rata & \\
\hline 1 & Butir 1 & 3 & 2 & 4 & 9 & 3 & Cukup \\
\hline 2 & Butir 2 & 3 & 2 & 3 & 8 & 2.6 & Kurang \\
\hline 3 & Butir 3 & 2 & 4 & 3 & 9 & 3 & Cukup \\
\hline 4 & Butir 4 & 4 & 3 & 4 & 11 & 3.6 & Baik \\
\hline 5 & Butir 5 & 2 & 3 & 3 & 8 & 2.6 & Kurang \\
\hline 6 & Butir 6 & 3 & 3 & 4 & 7 & 3.3 & Cukup \\
\hline 7 & Butir 7 & 4 & 3 & 2 & 9 & 3 & Cukup \\
\hline 8 & Butir 8 & 3 & 3 & 4 & 10 & 3.3 & Cukup \\
\hline 9 & Butir 9 & 3 & 5 & 3 & 11 & 3.6 & Baik \\
\hline 10 & Butir 10 & 4 & 3 & 4 & 11 & 3.6 & Baik \\
\hline 11 & Butir 11 & 3 & 4 & 3 & 10 & 3.3 & Cukup \\
\hline 12 & Butir 12 & 3 & 4 & 3 & 10 & 3.3 & Cukup \\
\hline 13 & Butir 13 & 3 & 3 & 3 & 9 & 3 & Cukup \\
\hline 14 & Butir 14 & 3 & 3 & 2 & 8 & 2,6 & Kurang \\
\hline 15 & Butir 15 & 3 & 2 & 3 & 8 & 2,6 & Kurang \\
\hline 16 & Butir 16 & 3 & 4 & 3 & 10 & 3,3 & Cukup \\
\hline 17 & Butir 17 & 2 & 3 & 3 & 8 & 2,6 & Kurang \\
\hline 18 & Butir 18 & 4 & 2 & 2 & 8 & 2,6 & Kurang \\
\hline 19 & Butir 19 & 5 & 3 & 3 & 11 & 3,6 & Baik \\
\hline 20 & Butir 20 & 3 & 4 & 3 & 10 & 3.3 & Cukup \\
\hline & & Jumlah & $\mathbf{1 8 5}$ & & $\mathbf{6 1 , 6 6}$ & \\
& & & & & & &
\end{tabular}

Berdasarkan pedoman konversi data kuantitatif ke data kualitatif, maka produk Adobe Flash CS6 termasuk kategori "kurang". Artinya mahasiswa

\footnotetext{
${ }^{9}$ Eko Putro Widyoko, Evaluasi Program Pembelajaran (Yogyakarta: Pustaka Pelajar, 2010).
} 
belum begitu antusias terhadap penyampaian materi dengan Adobe Flash CS6. Sehingga mereka memberikan nilai produk sesuai apa yang mereka lihat dan mereka amati.

\section{b) Uji Coba Kategori Sedang}

Pada tahap main field testing (data observasi dan kuesioner dikumpulkan dan dianalisis). Tahap ini jumlah subyek uji coba berjumlah 6 orang mahasiswa, semua mahasiswa lulusan dari sekolah umum (SMK dan SMA). Uji coba kategori sedang ini dilaksanakan pada tanggal 18 September 2019. Adapun hasil uji coba kategori sedang sebagai berikut:

\section{Tabel 4. ujicoba skala sedang}

\begin{tabular}{cccccccccc} 
No & $\begin{array}{c}\text { Indikat } \\
\text { or }\end{array}$ & $\mathbf{1}$ & $\mathbf{2}$ & $\mathbf{3}$ & $\mathbf{4}$ & $\mathbf{5}$ & $\mathbf{6}$ & Jumlah & $\begin{array}{c}\text { Rata- } \\
\text { rata }\end{array}$ \\
\cline { 2 - 7 } 1 & Butir 1 & 4 & 3 & 3 & 4 & 3 & 4 & 21 & 3.5 \\
\hline 2 & Butir 2 & 3 & 3 & 3 & 4 & 4 & 3 & 20 & 3.3 \\
\hline 3 & Butir 3 & 4 & 4 & 3 & 5 & 3 & 4 & 27 & 4.5 \\
\hline 4 & Butir 4 & 4 & 3 & 3 & 4 & 5 & 4 & 23 & 3.8 \\
\hline 5 & Butir 5 & 4 & $\underline{5}$ & 3 & $\underline{5}$ & 4 & 3 & 24 & 4 \\
\hline 6 & Butir 6 & 4 & 5 & 4 & 4 & 3 & 4 & 24 & 4 \\
\hline 7 & Butir 7 & 4 & 3 & 4 & 4 & 4 & 5 & 24 & 4 \\
\hline 8 & Butir 8 & 3 & 4 & 3 & 4 & 3 & 4 & 21 & 3.5 \\
\hline 9 & Butir 9 & 4 & 3 & 4 & 4 & 5 & 4 & 24 & 4 \\
\hline 10 & Butir 10 & 4 & 4 & 3 & 3 & 4 & 4 & 22 & 3.6 \\
\hline 11 & Butir 11 & 4 & 4 & 3 & 4 & 3 & 3 & 21 & 3.5 \\
\hline 12 & Butir 12 & 3 & 5 & 4 & 4 & 5 & 4 & 25 & 4.1 \\
\hline 13 & Butir 13 & 3 & 4 & 3 & 4 & 5 & 3 & 25 & 4.1 \\
\hline 14 & Butir 14 & 4 & 3 & 4 & 3 & 4 & 3 & 21 & 3,5 \\
\hline 15 & Butir 15 & 5 & 2 & 4 & 5 & 4 & 3 & 23 & 3,8 \\
\hline 16 & Butir 16 & 3 & 3 & 5 & 2 & 5 & 4 & 22 & 3,6 \\
\hline 17 & Butir 17 & 4 & 4 & 3 & 5 & 4 & 5 & 25 & 4,1 \\
\hline 18 & Butir 18 & 3 & 4 & 5 & 4 & 5 & 4 & 25 & 4,1 \\
\hline 19 & Butir 19 & 5 & 2 & 4 & 5 & 4 & 3 & 23 & 3,8 \\
\hline 20 & Butir 20 & 3 & 3 & 3 & 4 & 4 & 3 & 20 & 3.3 \\
\hline & & & Jumlah & & & & $\mathbf{4 8 2}$ & $\mathbf{8 0 , 3 3}$
\end{tabular}

Jumlah skor yang telah diperoleh pada uji coba tahap sedang ini yaitu 482 . Bila dihitung dihitung rata-rata mencapai 80,33. Hasil tersebut menunjukkan peningkatan yang cukup baik dibandingkan hasil ujicoba sebelumnya. Mengacu pada konversi data kuantitatif ke data kualitatif, maka aplikasi Adobe Flash CS6 bagi mahasiswa termasuk kategori "baik". Sesuai pengamatan 
peneliti dalam proses pembelajaran berbasis Adobe Flash CS6, subjek ujicoba tampak merasa antusias untuk belajar karena dianggap ada hal baru.

c. Uji coba lapangan

Skor keseluruhan yang diperoleh sebesar 3.287. Setelah dilakukan konversi data, maka produk aplikasi Adobe Flash CS6 termasuk kategori "baik" mahasiswa tidak saja memberikan peniliain bersifat kuantitatif tetapi mereka juga memberikan penilain secara kualitatif bahwa produk aplikasi Adobe Flash CS6 sangat membantu mereka dalam memahami materi bahasa Arab melalui media komputer secara mandiri.

\section{Data Screening}

Menurut Ghazali (2016) sebelum melakukan uji statistik langkah awal yang harus dilakukan adalah screening terhadap data yang akan diolah. Salah satu asumsi penggunaan statistik parametrik adalah asumsi multivariate normality yang merupakan asumsi bahwa setiap variabel berdistribusi normal. Asumsi multivariate normality ini dapat diuji dengan melihat normalitas. ${ }^{10}$ Menurut Ghazali (2016) screening terhadap normalitas data merupakan langkah awal yang harus dilakukan untuk setiap analisis multivariate, khususnya jika tujuannya adalah inferensi. Uji normalitas diperlukan dalam analisis untuk menghasilkan uji statistik yang lebih baik jika semua variabel berdistribusi normal. Untuk menguji normalitas dapat dilakukan dengan cara melihat distribusi data dari variabelvariabel yang akan diteliti melalui Non-parametrik statistik dengan uji Kolmogorov Smirnov. Analisa dari hasil pengujian Kolmogorov Smirnov (Ghozali, 2016) yaitu:

a) Jika nilai signifikansi (Sig) > 0,05 maka data berdistribusi normal.

b) Jika nilai signifikansi (Sig) $<0,05$ maka data berdistribusi tidak normal. ${ }^{11}$

Hasil uji normalitas dapat dilihat dalam tabel berikut:

\section{Tabel 5. Uji Normalitas}

Tests of Normality

\begin{tabular}{|l|l|l|l|l|l|l|}
\hline & \multicolumn{3}{|l|}{ Kolmogorov-Smirnov } & \multicolumn{3}{l|}{ Shapiro-Wilk } \\
\cline { 2 - 7 } & Statistik & df & Sig. & Statistik & Df & Sig. \\
\hline Pre & 112 & 40 & $.200^{*}$ & .950 & 40 & .079 \\
Post & 131 & 40 & .081 & .948 & 40 & .064 \\
\hline
\end{tabular}

10 Imam Ghazali, Aplikasi Analisis Multivariate Dengan Program IBM SPSS 23, Cetakan Ketujuh (Semarang: Badan Penerbit Universitas Diponegoro, 2016), 27.

11 Ghazali, 30. 
Tests of Normality

\begin{tabular}{|l|l|l|l|l|l|l|}
\hline \multirow{2}{*}{} & \multicolumn{3}{|l|}{ Kolmogorov-Smirnov } & \multicolumn{3}{l|}{ Shapiro-Wilk } \\
\cline { 2 - 7 } & Statistik & df & Sig. & Statistik & Df & Sig. \\
\hline Pre & 112 & 40 & $.200^{*}$ & .950 & 40 & .079 \\
Post & 131 & 40 & .081 & .948 & 40 & .064 \\
\hline
\end{tabular}

a. Lilliefors Significance Correction

*. This is a lower bound of the true significance.

Berdasarkan tabel di atas terlihat bahwa data minat belajar bahasa Arab mahasiswa GMI.B IAIN Ponorogo sebelum (pre-test) dan sesudah (post-test) penggunaan desain materi ajar pembelajaran bahasa Arab berbasis Adobe Flash CS6 dalam penelitian ini memiliki nilai Sig. > 0,05, sehingga dinyatakan data berdistribusi normal.

\section{Analisis Uji Beda}

Untuk menguji perbedaan minat belajar bahasa Arab mahasiswa GMI.B IAIN Ponorogo sebelum (pre-test) dan sesudah (post-test) penggunaan desain materi ajar pembelajaran bahasa Arab berbasis Adobe Flash CS6 dilakukan uji paired sample t-test jika data berdistribusi normal. ${ }^{12}$ Namun, jika data tidak berdistribusi normal maka dapat dilakukan uji Wilcoxon. $^{13}$ Berdasarkan hasil pengujian normalitas sebelumnya yang menunjukkan bahwa data berdistribusi normal, maka dapat disimpulkan bahwa uji beda dalam penelitian ini menggunakan uji paired sample t-test. Hasil uji paired sample t-test pada penelitian ini adalah sebagai berikut:

Tabel 6. Statistik Deskriptif

Paired Samples Statistiks

\begin{tabular}{|c|c|c|c|c|}
\hline & Mean & $\mathrm{N}$ & $\begin{array}{l}\text { Std. } \\
\text { Deviation }\end{array}$ & Std. Error Mean \\
\hline \multirow{2}{*}{$\begin{aligned} \text { Pair } 1 & \text { Pre } \\
& \text { Post }\end{aligned}$} & 75.88 & 40 & 8.884 & 1.405 \\
\hline & 87.88 & 40 & 5.044 & .798 \\
\hline
\end{tabular}

Berdasarkan statistik deskriptif menunjukkan bahwa minat belajar bahasa Arab mahasiswa GMI.B IAIN Ponorogo sebelum (pre-test) penggunaan desain materi ajar pembelajaran bahasa Arab berbasis Adobe Flash CS6 memiliki nilai rata-rata sebesar 75,88, dan nilai standar deviasi sebesar 1,405 yang menunjukkan

\footnotetext{
12 Ghazali, 163.

13 Imam Ghazali, Statistik Non Parametrik Teori Dan Aplikasi Dengan Program IBM SPSS 23 (Semarang: Badan Penerbit Universitas Diponegoro, 2015).
} 
variasi data minat belajar bahasa Arab mahasiswa GMI.B IAIN Ponorogo sebelum (pre-test) penggunaan desain materi ajar pembelajaran bahasa Arab berbasis Adobe Flash CS6 yang tinggi. Sedangkan minat belajar bahasa Arab mahasiswa GMI.B IAIN Ponorogo sesudah (post-test) penggunaan desain materi ajar pembelajaran bahasa Arab berbasis Adobe Flash CS6 memiliki nilai rata-rata sebesar 87,88 , dan nilai standar deviasi sebesar 0,798 yang menunjukkan variasi data minat belajar bahasa Arab mahasiswa GMI.B AIN Ponorogo sesudah (posttest) penggunaan desain materi ajar pembelajaran bahasa Arab berbasis Adobe Flash CS6 yang rendah.

Sedangkan hasil uji paired sample t-test minat belajar bahasa Arab mahasiswa GMI.B IAIN Ponorogo sebelum (pre-test) dan sesudah (post-test) penggunaan desain materi ajar pembelajaran bahasa Arab berbasis Adobe Flash CS6 adalah sebagai berikut:

Tabel 7. Uji Paired Sample t-test

Paired Samples Test

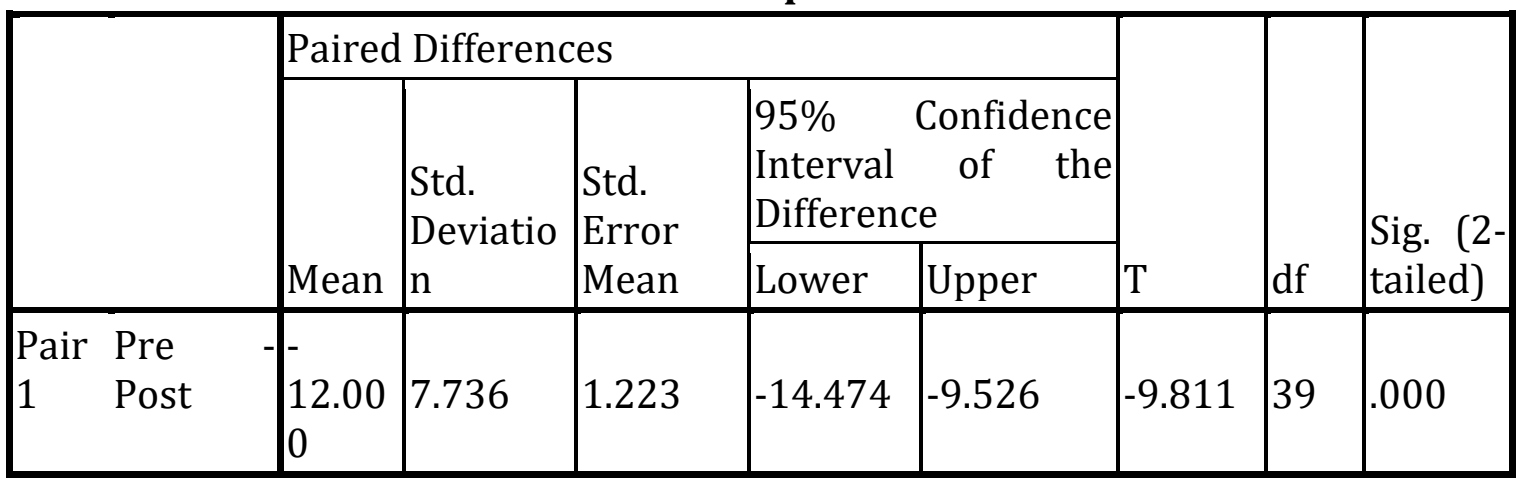

Hasil perhitungan uji paired sample t-test minat belajar bahasa Arab mahasiswa GMI.B IAIN Ponorogo sebelum (pre-test) dan sesudah (post-test) penggunaan desain materi ajar pembelajaran bahasa Arab berbasis Adobe Flash CS6 memperoleh nilai signifikan sebesar 0,000<0,05, sehingga dapat disimpulkan bahwa Ho1 ditolak dan Ha1 diterima, artinya terdapat perbedaan minat belajar bahasa Arab mahasiswa GMI.B IAIN Ponorogo antara sebelum dan sesudah penggunaan desain materi ajar pembelajaran bahasa Arab berbasis Adobe Flash CS6 dengan selisih perbedaan rata-rata sebesar 12.

\section{Analisis dan Pembahasan}

Hasil analisis uji beda minat belajar bahasa Arab mahasiswa GMI.B IAIN Ponorogo sebelum (pre-test) dan sesudah (post-test) penggunaan desain materi 
ajar pembelajaran bahasa Arab berbasis Adobe Flash CS6 dengan uji paired sample $t$ test menghasilkan nilai signifikansi $0,000<0,05$ sehingga dapat disimpulkanybahwa Ho1 ditolak dan Ha1 diterima. Hasil tersebut menunjukkan bahwa terdapat perbedaan minat belajar bahasa Arab mahasiswa GMI.B IAIN Ponorogo antara sebelum dan sesudah penggunaan desain materi ajar pembelajaran bahasa Arab berbasis Adobe Flash CS6 dengan selisih perbedaan rata-rata sebesar 12 .

Adanya perbedaan minat belajar bahasa Arab mahasiswa GMI.B IAIN Ponorogo antara sebelum dan sesudah penggunaan desain materi ajar pembelajaran bahasa Arab berbasis Adobe Flash CS6 dibuktikan dengan perbedaan rata-rata masing-masing pengujian pre test dan post test. Hasil pengujian pre test minat belajar bahasa Arab mahasiswa GMI.B IAIN Ponorogo sebelum penggunaan desain materi ajar pembelajaran bahasa Arab berbasis Adobe Flash CS6 menghasilkan rata-rata sebesar 75,88. Sedangkan hasil pengujian post test minat belajar bahasa Arab mahasiswa GMI.B IAIN Ponorogo sesudah penggunaan desain materi ajar pembelajaran bahasa Arab berbasis Adobe Flash CS6 menghasilkan rata-rata sebesar 87,88. Berdasarkan hasil tersebut dapat disimpulkan bahwa penggunaan desain materi ajar pembelajaran bahasa Arab berbasis Adobe Flash CS6 efektif dapat meningkatkan minat belajar bahasa Arab mahasiswa GMI.B IAIN Ponorogo.

\section{SIMPULAN}

Proses pengembangan media pembelajaran berbasis Adobe Flash CS6 pada materi Bahasa Arab 1 dikembangkan melalui prosedur pengembangan multimedia yang terdiri dari tahap analysis yaitu melakukan identifikasi kebutuhan berdasarkan observasi kondisi kelas dan wawancara dengan mahasiswa untuk mengetahui kemampuan dan pemahaman bahasa Arab mereka. Planning, desain materi ajar bahasa Arab berbasis Adobe Flash CS6 ini diperuntuk bagi mahasiswa semester I, kompetensi yang dimiliki mahasiswa adalah memahami materi ajar dengan baik, tujuan desain materi dengan Adobe Flash CS6 adalah memudahkan mereka dalam belajar dan memiliki minat untuk belajar bahasa Arab. Development, Pada tahap ini meliputi: kegiatan penyusunan bahan ajar bahasa Arab berbasis Adobe Flash CS6, pengumpulan bahan/materi ajar, pembuatan gambar-gambar ilustrasi, dan 
pengetikan sehingga menghasilkan materi ajar bahasa Arab sejumlah 6 bab pembahasan. Media pembelajaran divalidasi oleh satu orang ahli media dan dua orang ahli materi, kemudian diujicobakan pada 40 mahasiswa GMI.B IAIN Ponorogo.

Hasil analisis uji beda minat belajar bahasa Arab mahasiswa GMI.B IAIN Ponorogo sebelum (pre-test) dan sesudah (post-test) penggunaan desain materi ajar pembelajaran bahasa Arab berbasis Adobe Flash CS6 dengan uji paired sample t test menghasilkan nilai signifikansi $0,000<0,05$. Sehingga dapat disimpulkan bahwa Ho1 ditolak dan Ha1 diterima. Hasil tersebut menunjukkan bahwa terdapat perbedaan minat belajar bahasa Arab mahasiswa GMI.B IAIN Ponorogo antara sebelum dan sesudah penggunaan desain materi ajar pembelajaran bahasa Arab berbasis Adobe Flash CS6 dengan selisih perbedaan rata-rata sebesar 12.

Adanya perbedaan minat belajar bahasa Arab mahasiswa GMI.B IAIN Ponorogo antara sebelum dan sesudah penggunaan desain materi ajar pembelajaran bahasa Arab berbasis Adobe Flash CS6 dibuktikan dengan perbedaan rata-rata masing-masing pengujian pre test dan post test. Hasil pengujian pre test minat belajar bahasa Arab mahasiswa GMI.B IAIN Ponorogo sebelum penggunaan desain materi ajar pembelajaran bahasa Arab berbasis Adobe Flash CS6 menghasilkan rata-rata sebesar 75,88. Sedangkan hasil pengujian post test minat belajar bahasa Arab mahasiswa GMI.B IAIN Ponorogo sesudah penggunaan desain materi ajar pembelajaran bahasa Arab berbasis Adobe Flash CS6 menghasilkan rata-rata sebesar 87,88. Berdasarkan hasil tersebut dapat disimpulkan bahwa penggunaan desain materi ajar pembelajaran bahasa Arab berbasis Adobe Flash CS6 efektif dapat meningkatkan minat belajar bahasa Arab mahasiswa GMI.B IAIN Ponorogo.

\section{DAFTAR PUSTAKA}

Ghazali, Imam. Aplikasi Analisis Multivariate Dengan Program IBM SPSS 23, Cetakan Ketujuh. Semarang: Badan Penerbit Universitas Diponegoro, 2016.

-_- Statistik Non Parametrik Teori Dan Aplikasi Dengan Program IBM SPSS 23. Semarang: Badan Penerbit Universitas Diponegoro, 2015.

I Made Tegeh, Dkk. Model-Model Penelitian Pengembangan. Yogyakarta: Graha Ilmu, 2014.

Jamarah, Syaiful Bahri. Psikologi Belajar Edisi 2. Jakarta: PT.Rineka Cipta, 2008.

Prastowo, Andi. Panduan Kreatif Membuat Bahan Ajar Inovatif. Yogyakarta: Diva Press, 2011.

Shiddiq, Jamaluddin. "Inovasi Pemanfaatan Word-Wall Sebagai Media Game-Based 
Learning Untuk Bahasa Arab." JALIE; Journal of Applied Linguistics and Islamic Education 5, no. 1 (2021): 151-69.

Shofiani, Ikas. "Modul Pelatihan Pembuatan Media Pembelajaran Menggunakan Adobe Flash CS3 Professional. Diakses Dari Https://Ikashofiani.Files.Wordpress.Com/2012/05/Modul-Pelatihan-AdobeFlash-Cs3-Professional.Pdf Pada Tanggal 28 November 2015," 2012.

Sutopo, Ariesto Hadi. Teknologi Informasi Dan Komunikasi Dalam Pendidikan. Yogyakarta: Graha Ilmu, 2012.

Syah, Muhibbin. Psikologi Pendidikan Dengan Pendeketan Baru. Bandung: Rosdakarya, 2006.

Wibowo, Wahyu. Penulisan Buku Ajar Perguruan Tinggi: Hakekat, Formulasi Dan Problem Etisnya. Jakarta: Penerbit RajaGrafindo Persada, 2012.

Widyoko, Eko Putro. Evaluasi Program Pembelajaran. Yogyakarta: Pustaka Pelajar, 2010. 